\title{
Comparative analysis of plant use in peri-urban domestic gardens of the Limpopo Province, South Africa
}

\author{
Gabolwelwe KE Mosina', Alfred Maroyi ${ }^{2^{*}}$ and Martin J Potgieter ${ }^{3}$
}

\begin{abstract}
Background: Relatively little has been researched or published on the importance of peri-urban domestic gardens as part of a household livelihood strategy in South Africa. Due to lack of comprehensive data on peri-urban domestic gardens, their potential value as luxury green space, provision of food, income and ecosystem services to the fast growing urban population in South Africa is not clearly known. The aim of this study was to document differences and similarities in plant use and diversity in domestic gardens of two peri-urban communities in the Limpopo Province that differ in proximity to an urban area.
\end{abstract}

Methods: Data on plant use categories of 62 domestic gardens in the peri-urban areas of the Limpopo Province were collected in Seshego and Lebowakgomo. Semi-structured interviews, observation and guided field walks with 62 participants were employed between May and October 2012.

Results: A total of 126 plant species were recorded for both Seshego and Lebowakgomo. Domestic gardens in the more remote areas of Lebowakgomo were characterized by higher percentage of food plants ( 47 species, $83.8 \%$ of the total food plants recorded) and medicinal plants (31 species, 83.7\%). Lebowakgomo domestic gardens were also characterized by higher numbers of indigenous plants (76.7\%) showing similarities to the natural surrounding vegetation in terms of plant species. On the contrary, domestic gardens of Seshego on the periphery of the city centre were characterized by higher percentage of exotic species (81.8\%) and ornamental plants (73\%), with food plants playing a supplementary role. Comparison of the two areas demonstrated a remarkable difference in plant use and composition.

Conclusions: This study revealed that there are differences in utilization of plant resources between households on the edge of an urban centre and those in the more remote areas. Food and medicinal plants play an important role in remote areas; while ornamental plants play an important role in urban domestic gardens. But the collective desire for food, medicinal and ornamental plants by both communities on the edge of an urban centre and those in the more remote areas highlight the importance of plant resources in domestic gardens.

Keywords: Cultivated plants, Limpopo Province, Livelihoods, Peri-urban, Urbanisation, Useful plants

\section{Background}

There is growing interest in the documentation of goods and services provided by home gardens throughout the world [1,2], including South Africa [3-7]. The Millennium Ecosystem Assessment [8] defined goods and services as the benefits that humans obtain from natural or semi-natural ecosystems. Fernandes and Nair [1] defined

\footnotetext{
*Correspondence: amaroyi@ufh.ac.za

${ }^{2}$ Medicinal Plants and Economic Development (MPED) Research Center; Department of Botany, University of Fort Hare, Private Bag X1314, Alice 5700, South Africa

Full list of author information is available at the end of the article
}

a home garden as an intensively worked land-use system involving deliberate management of multipurpose plants in association with agricultural crops and invariably livestock, within the compounds of individual households. Researchers suggest that, besides the provisioning of food, fuel and medicines; home gardens also provide cultural, regulating services and serve as a habitat to other organisms. Based on studies conducted in the North West Province, South Africa, Molebatsi et al. [4], defined a domestic garden as a luxury space around the house used for relaxation, play areas, keeping pets, outdoor 
eating and cultivation of ornamental plants. Urban domestic gardens provide multiple ecosystem services that contribute to quality of life in cities, air quality regulation, carbon capturing [9], temperature regulation [10], storm water run-off mitigation [11], as well as recreational benefits and social cohesion [12]. Kuruneri-Chitepo and Shackleton [13] showed that urban biodiversity enables urban inhabitants to interact with nature, thereby enhancing appreciation and understanding of the important ecological, social and psychological functions green areas perform.

The main difference between urban and rural gardens lies in the purpose and use of the gardens, resulting in different species grown and maintained in these gardens. A rural home garden is regarded as part of a household livelihood strategy, a natural asset through which sustainable use of resources, particularly for the livelihoods of the poor are achieved [14]. Nair [15] showed that high number of ornamental plants in urban gardens is associated with the aesthetic role of domestic gardens in cities, since they are not used for subsistence, except among low income city dwellers. Similarly, Reichard and White [16] showed that large number of plant species introduced into the urban environment are for horticultural purposes. Relatively little has been researched or published on the importance of peri-urban domestic gardens in South Africa. Due to lack of comprehensive data on peri-urban domestic gardens, their potential value as luxury green space, provision of food, income and ecosystem services to the fast growing urban population in South Africa is not clearly known. For the purpose of this study, a home garden is defined as an area adjacent to a household dwelling, where the household has control over the area characterized by a diversity of organisms, hereafter referred to as the domestic garden.

The peri-urban areas are formerly "rural" localities that are now due to the rapid expansion of South Africa's metros and major towns lie outside the urban edge [17]. The wealth gap between rich and poor in South Africa is most visible on the urban outskirts. Apartheid spatial planning policies was racially-based and segregated black populations in areas some distance from urban cores, while whites resided in suburbs typical of any city in the first world [18]. As a result of this racially-based ideology, South Africa's urban peripheries are usually occupied by the poor [17]. Most informal settlements evolve on the urban edge and low cost, subsidised housing developments to improve the lives of the poor tend to be located in the same areas [19]. The same author found that the peri-urban poor lead multifaceted livelihoods characterized by small scale farming which contributes to household's income and nutritional needs. This study was therefore undertaken within the wider problem of understanding the differences and similarities in plant use and diversity in two peri-urban communities in the Limpopo Province of South Africa that differ in proximity to an urban area. Our hypothesis states that food production in domestic gardens is important for households in remote areas and becomes less important for households on the edge of an urban centre. We tested this hypothesis by compiling a list of plant use categories, assessed their importance in domestic gardens and how indigenous and non-native plants were used by both households on the edge of an urban centre and those in the more remote areas.

\section{Materials and methods Study area}

The study was conducted in Seshego $\left(23^{\circ} 15^{\prime} \mathrm{S} 29^{\circ} 23^{\prime} \mathrm{E}\right)$

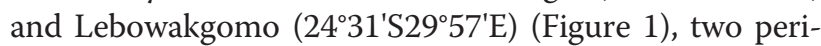
urban areas in the Capricorn District, Limpopo Province. Limpopo Province is a predominantly rural province with $86.7 \%$ of its population living in the rural areas in 2008 [20]. Most urban settlements in the province are informal and there are no metropolitan centres. A metropolitan centre is a municipality that execute all the functions of local government for a city, and that have sufficient resources to perform municipal function [21]. The rural character of the province further highlights that Limpopo Province is not an industrialized province. The province's source of economic activities are centred principally around agriculture and mining [22]. The province has the second highest estimated net migration after the Eastern Cape Province [23]. The migration trend can be attributed mainly to the rural character of the province, which has led to economically active people migrating either to Polokwane municipality or the more industrialized neighbouring province of Gauteng [22]. Polokwane municipality is located at the centre of the Limpopo Province and it is situated at the core of the province's economic development. Polokwane is developing at a rapid pace and the mining industry has boomed over the last decade. Situated on the outskirts of Polokwane municipality are Seshego and Lebowakgomo, which are less formal settlements experiencing enormous influx from rural to urban migration trends. Seshego is located $13 \mathrm{~km}$ north of Polokwane and the township was planned as a dormitory town for workers in Polokwane city [24]. Seshego is nearest to the economic core of Polokwane and thus has the best access to the formal economy of the city. Lebowakgomo is located $55 \mathrm{~km}$ south of Polokwane. The main employment sector in Lebowakgomo is the mining industry. These areas are in dire need of upgraded physical infrastructure, services and economic prospects of employment to cope with the informal influx of more people who want access to an improved quality and standard of living. 


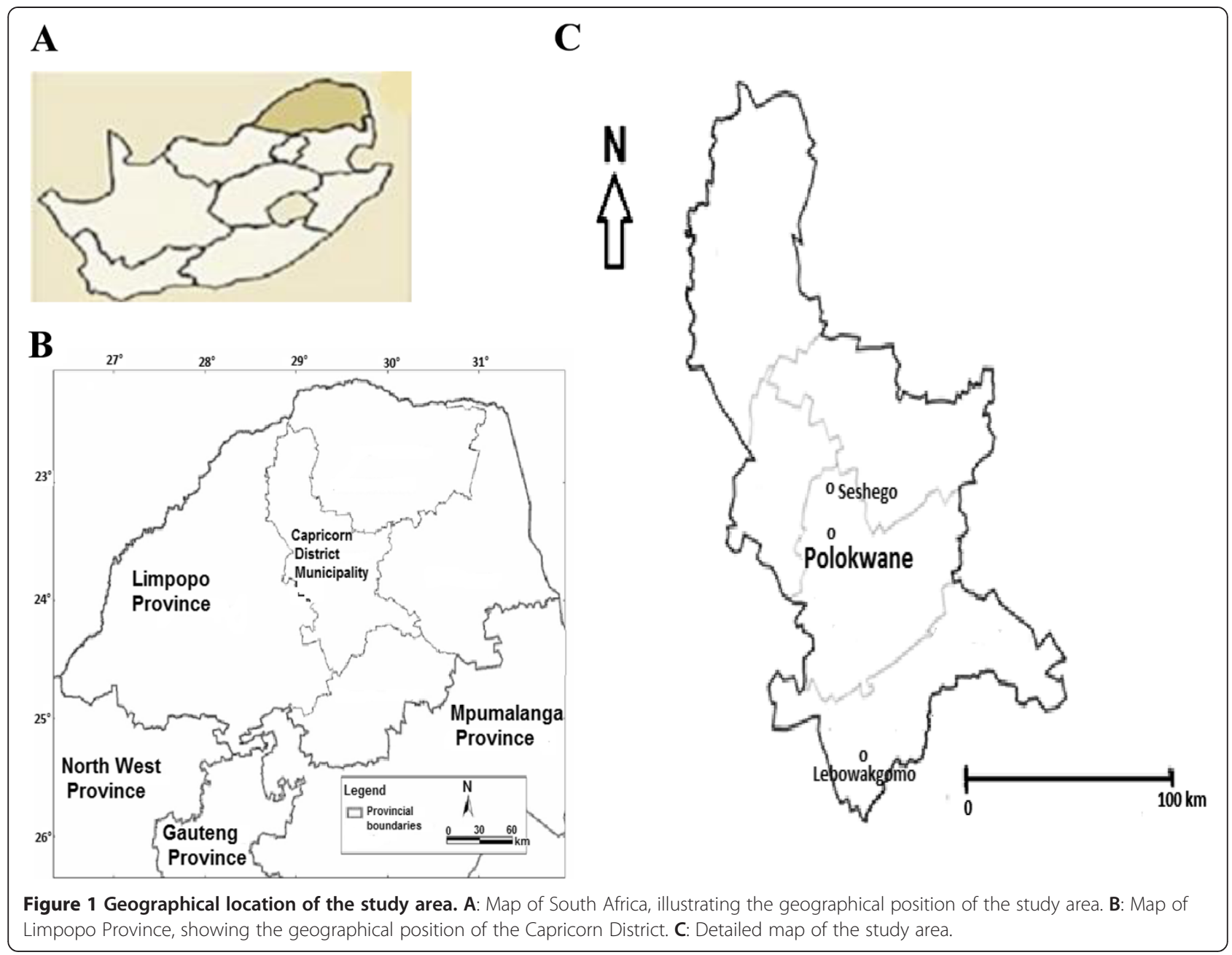

The studied areas are semi-arid, susceptible to frequent droughts and characterized by summer rainfall. Mean annual rainfall ranges from 300 to $500 \mathrm{~mm}$ [25]. Daily temperatures vary from mid $-20^{\circ} \mathrm{C}$ to mid- $30^{\circ} \mathrm{C}$, with an average range of between $17^{\circ} \mathrm{C}$ and $27^{\circ} \mathrm{C}$ in summer and $4^{\circ} \mathrm{C}$ to $20^{\circ} \mathrm{C}$ in winter [26]. According to the vegetation classification of Mucina and Rutherford [27], the study areas have a semi-arid savanna, characterized by a mixture of trees, shrubs and grasses. Dominant tree species include Acacia spp., Albizia spp., Combretum spp. and Sclerocarya birrea, with patches of Hyparrhenia spp., Eragrostis spp., Heteropogon spp. and Digitaria spp. grasses.

\section{Data collection}

Data on plant use categories in urban domestic gardens of Seshego and Lebowakgomo were collected by means of semi-structured and structured interviews and personal observation. Thirty one randomly selected individuals from each study area were interviewed between May and October 2012 (Table 1). Table 1 shows the demographic characteristics of the participants. Of the sixty two participants, $69.4 \%$ were female and $30.6 \%$ were male. Their ages ranged from 19 to 73 years, with 48 years as the median. The majority of participants were married (58.1\%), 32.3\% divorced and 9.7\% single (Table 1$)$. The majority of households $(80.7 \%)$ comprised between three and six family members, while $17.7 \%$ lived alone and one household had seven family members (Table 1 ). The majority (53.2\%) of the participants were educated up to secondary level, while $29 \%$ had attained tertiary education, $11.3 \%$ had attained primary level and $6.5 \%$ were illiterate. More than half of the participants (56.5\%) were unemployed, surviving on less than R2000 (US\$200) a month (Table 1). A very small proportion of the participants had constant income as either selfemployed (14.5\%) or employed by a company (29\%) and $27.4 \%$ of the participants did not disclose their monthly income (Table 1).

Verbal informal consent was obtained from each individual who participated in the study, and the researchers adhered to the ethical guidelines of the International 
Table 1 Socio-economic characteristics of the study sample, $\mathbf{N}=\mathbf{6 2}$

\begin{tabular}{|c|c|c|c|}
\hline \multicolumn{2}{|l|}{ Socio-economic variables } & \multirow{2}{*}{$\begin{array}{l}\text { Number } \\
43\end{array}$} & \multirow{2}{*}{$\begin{array}{l}\% \\
30.6\end{array}$} \\
\hline Gender & Female & & \\
\hline & Male & 19 & 69.4 \\
\hline \multirow[t]{6}{*}{ Age (years) } & $<20$ & 1 & 1.6 \\
\hline & $20-29$ & 11 & 17.7 \\
\hline & $30-39$ & 10 & 16.1 \\
\hline & $40-49$ & 17 & 27.4 \\
\hline & $50-59$ & 11 & 17.7 \\
\hline & $>60$ & 12 & 19.4 \\
\hline \multirow[t]{3}{*}{ Marital status } & Single & 6 & 9.7 \\
\hline & Married & 36 & 58.1 \\
\hline & Divorced & 20 & 32.3 \\
\hline \multirow[t]{4}{*}{ Household size } & $1-2$ & 11 & 17.7 \\
\hline & $3-4$ & 28 & 45.2 \\
\hline & $5-6$ & 22 & 35.5 \\
\hline & $7-8$ & 1 & 1.6 \\
\hline \multirow[t]{4}{*}{ Highest level of education } & No education & 4 & 6.5 \\
\hline & Primary & 7 & 11.3 \\
\hline & Secondary & 33 & 53.2 \\
\hline & Tertiary & 18 & 29.0 \\
\hline \multirow[t]{3}{*}{ Occupation } & Unemployed & 35 & 56.5 \\
\hline & Employed & 18 & 29.0 \\
\hline & Self-employed & 9 & 14.5 \\
\hline \multirow[t]{7}{*}{ Combined monthly income } & Less than R1000* & 22 & 35.5 \\
\hline & R1001-2000 & 7 & 11.3 \\
\hline & R2001-3000 & 7 & 11.3 \\
\hline & R3001-4000 & 4 & 6.5 \\
\hline & R4001-5000 & 2 & 3.2 \\
\hline & More than R5001 & 3 & 4.8 \\
\hline & Not disclosed & 17 & 27.4 \\
\hline
\end{tabular}

*1 Rand = US\$0.1.

Society of Ethnobiology (www.ethnobiology.net). The aim and purpose of the investigation was explained to selected participants. The questionnaire used during interviews was designed to gather data on socio-economic characteristics of the participants and useful plant species (food, medicinal and ornamental) grown and maintained in the domestic gardens. A plant species was included in this study if the domestic garden owner could indicate its use. Voucher specimens of plants identified in domestic gardens were collected during the field trips when encountered for the first time and again when they were flowering or fruiting, for easy identification. The voucher specimens were processed using standard taxonomic procedures $[28,29]$. Each herbarium specimen included important parts such as leaves, stems, flowers and fruits whenever available. For small herbaceous plants, the whole plants were collected. These specimens were deposited for future reference at the Larry Leach Herbarium (UNIN) of the University of Limpopo.

\section{Data management and analysis}

The data collected were entered in Microsoft Excel 2007 programme and were later analyzed for descriptive statistical patterns. During analysis, data on useful plants as provided by the participants were summarized into major themes by content analysis [30]. Through content analysis, it was possible to distil words into fewer content-related categories, sharing the meaning [31]. Inconsistencies and unique statements were noted and given particular attention. Descriptive statistics, such as percentages and frequencies were used to analyse the data obtained from the questionnaires. Bar graphs were generated using Microsoft Excel 2007 programme.

Species are described as native or alien based on Pyšek et al. [32]. According to Pyšek et al. [32], naturalized species are defined as aliens that reproduce consistently without direct human intervention, and invasive aliens as naturalized species producing offspring in large numbers and at considerable distances from the parent plants with the potential to spread over a large area. This definition of invasive alien species used in this study is different from the Convention on Biological Diversity (CBD) Conference of Parties' definition of an invasive alien species, where an alien is defined as a species outside its indigenous geographic range, whose introduction and spread threatens biodiversity [33]. Another important species classification used in this study is the "indigenous cultivated" category, referring to species indigenous to South Africa and not occurring naturally in Seshego or Lebowakgomo, Limpopo Province, but cultivated in domestic gardens. The origin of "indigenous cultivated" species was determined from Germishuizen et al. [34]. In this study, the term "indigenous" is used to refer to a plant species that is naturally occurring and usually not cultivated in Seshego or Lebowakgomo, Limpopo Province, South Africa. Exotic is a plant species in Seshego or Lebowakgomo, Limpopo Province, whose presence there is due to intentional or unintentional human involvement or which has arrived there without the help of people from an area in which they are indigenous [32]. A weedy species is defined as a plant (not necessarily exotic) that grow in sites where it is not wanted and which has detectable economic or environmental impact or both [32].

\section{Results and discussion Plant diversity}

A total of 126 plant species used by both Seshego and Lebowakgomo residents was compiled. Lebowakgomo domestic gardens had higher species numbers (94 
species, $74.6 \%$ of the total) when compared to Seshego (84 species, $66.7 \%$ of the total) (Table 2). Lebowakgomo was also characterized by more plant families and genera than Seshego (Table 2). Asteraceae, Anacardiaceae and Rosaceae had at least five species in both Lebowakgomo and Seshego (Figure 2). Asteraceae, Anacardiaceae and Rosaceae are among the largest families in South Africa characterized by more than 100 species each [34]. Families Papilionaceae, Poaceae and Xanthorrhoeaceae were recorded in Lebowakgomo only, while Lamiaceae, Moraceae and Solanaceae were recorded in Seshego only (Figure 2). Seshego domestic gardens were characterized by higher number of exotic species, $81.8 \%$ of the total exotic species recorded in the study, while Lebowakgomo domestic gardens had higher proportion of indigenous species $(76.7 \%$ of the total indigenous species recorded in the study) (Table 2). Some of the indigenous species recorded in Lebowakgomo domestic gardens only were Erythrina lysistemon Hutch., Vigna unguiculata (L.) Walp. and Vigna subterranea (L.) Verdc. (Papilionaceae family), Aloe ecklonis Salm-Dyck and Aloe sp. (Xanthorrhoeaceae). Among the exotic species recorded in Seshego domestic gardens only were Lavandula angustifolia Mill. and Rosmarinus officinalis L. (members of Lamiaceae family), Ficus carica L. and Morus alba L. (Moraceae) and Capsicum frutescens L. and Lycopersicon esculentum L. (Solanaceae). Exotic species appear to dominate in the urbanized Seshego while in Lebowakgomo which lies on the outskirts of Polokwane city, the indigenous plant species showing similarities in terms of plant species to the natural vegetation of the area dominates. The dominance of exotic species in Seshego is mainly due to deliberate introductions of exotic species in domestic gardens. These results correlate strongly with previous research by McKinney [35] which showed that urbanization reduces the diversity and abundance of indigenous species, because of the homogenisation of the habitat in urban areas.

Lebowakgomo domestic gardens had higher number of "cultivated indigenous" species ( $75 \%$ of the total), against $41.7 \%$ recorded in Seshego domestic gardens (Table 2). Among these were the following species, introduced to Lebowakgomo domestic gardens from other

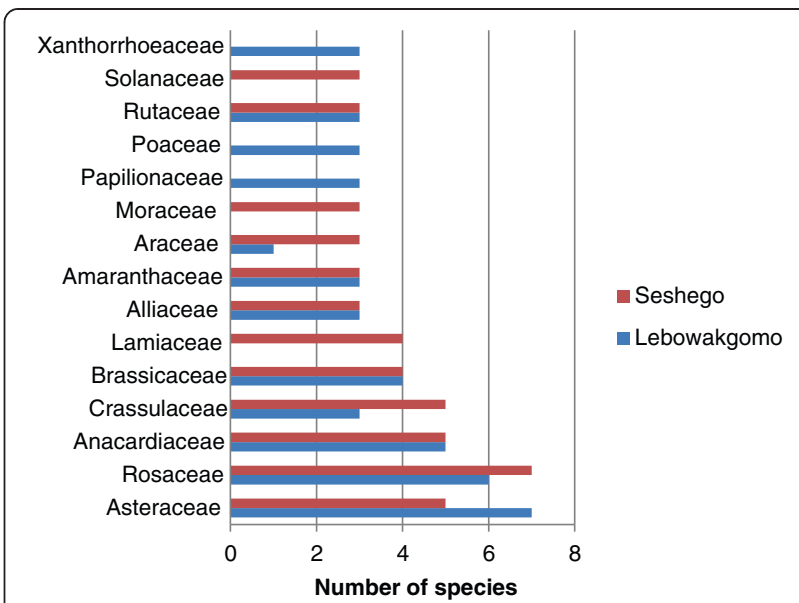

Figure 2 Families with the largest number of plants grown and maintained in domestic gardens of Lebowakgomo and Seshego in the Limpopo Province.

provinces of South Africa: Agapanthus africanus ssp africanus (Western Cape), Clivia miniata var. miniata (Eastern Cape, KwaZulu-Natal, Mpumalanga), Dietes grandiflora (Eastern Cape, KwaZulu-Natal), Drimiopsis maculata (Eastern Cape, Gauteng, KwaZulu- Natal, Mpumalanga), Euryops chrysanthemoides (Eastern Cape, KwaZulu-Natal), Haworthia fasciata (Eastern Cape), Pelargonium peltatum (Eastern Cape, Western Cape), Pelargonium zonale (Eastern Cape, KwaZulu-Natal, Western Cape), Strelitzia nicolai (Eastern Cape, KwaZulu-Natal) and Strelitzia reginae ssp reginae (Eastern Cape, KwaZulu-Natal). Begonia homonyma (Eastern Cape, KwaZulu-Natal), Haworthia fasciata, Lobostemon fruticosus (Western Cape), Pelargonium peltatum and Pelargonium zonale were introduced to Seshego domestic gardens. The number of "cultivated indigenous" species is higher in Lebowakgomo domestic gardens than in Seshego probably because households get these plants from two nurseries in Lebowakgomo, where "indigenous cultivated" species are readily available. Lubbe et al. [36] argued that home gardens in the Tlokwe municipality, North West Province, South Africa, have high number of ornamental plants because home gardeners get these plants from nurseries in the city and also nurseries are

Table 2 Summary of plant species grown and maintained in domestic gardens of Lebowakgomo and Seshego in the Limpopo Province

\begin{tabular}{|c|c|c|c|}
\hline & & Seshego (\%) & Lebowakgomo (\%) \\
\hline \multirow[t]{3}{*}{ Taxonomic rank } & Family & $45(72.6 \%)$ & $52(78.8 \%)$ \\
\hline & Genera & 77 (70\%) & $82(74.5 \%)$ \\
\hline & Species & $84(66.7 \%)$ & $94(74.6 \%)$ \\
\hline \multirow[t]{3}{*}{ Origin } & Exotic & $54(81.8 \%)$ & $48(72.7 \%)$ \\
\hline & Indigenous & $30(50 \%)$ & $46(76.7 \%)$ \\
\hline & Cultivated indigenous & $5(41.7 \%)$ & $9(75 \%)$ \\
\hline
\end{tabular}


promoting planting of ornamental plants. The presence of these species from other provinces may point out to the possibility of exchange and sharing of ethnobotanical information on these species. Previous research by Gilmore [37] showed that the relations of people to their useful plants and that of other regions near or further away aids in measuring their cultural status and their contacts with each other. Moreover, households give home garden products to neighbours and relatives, and this exchange between households and relatives strengthen relationships [38].

\section{Plant uses}

Eight major uses of domestic garden plants identified in this study (Figure 3) were: cereal, culinary herb, edible fruit, edible stem, edible tuber, medicinal, ornamental and vegetable. The dominant plant use category in Seshego domestic gardens was ornamental with 46 species $(73 \%$ of total ornamentals recorded) (Figure 3), followed by edible fruits (23 species, $79.3 \%$ ), medicinal (19 species, 51.4\%), vegetable (9 species, 50\%) and culinary herbs (5 species, 83.3\%). Important ornamental plants (grown and maintained by more than $50 \%$ of the participants) included Catharanthus roseus (L.) G. Don. (also used as medicine, Cyperus sexangularis Nees, Euryops chrysanthemoides (DC.) B. Nord. and Tecoma stans (L.) Juss. ex Kunth. Fruit trees grown and maintained by at least $50 \%$ of the participants included Carica papaya L. (also used as medicine), Citrus limon (L.) Burm. f., Citrus sinensis (L.) Osbeck, Mangifera indica L., Musa sp., Persea americana Mill., Prunus persica (L.) Stokes and Sclerocarya birrea (A. Rich.) Hochst. ssp caffra (Sond.) Kokwaro (also used as medicine). These results corroborate results obtained by Nair [15] and Eichemberg et al. [39], which showed high number

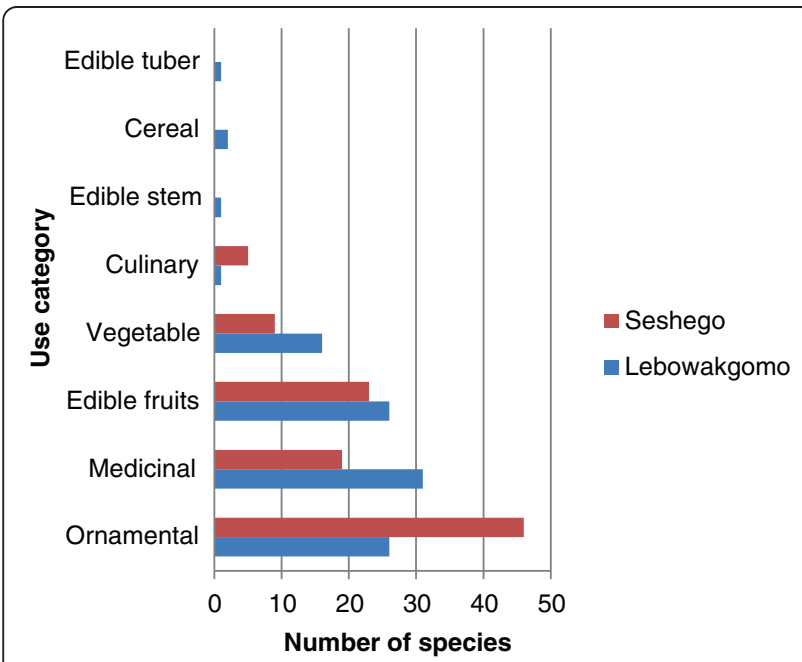

Figure 3 Number of plants used for food, medicine and as ornamentals in the Limpopo Province. of ornamental plants in urban gardens. Eichemberg et al. [39] assessed species composition in urban home gardens in Rio Claro municipality, southeast Brazil and documenting three major plant use categories, dominated by ornamentals $(63 \%)$, alimentary $(24 \%)$ and medicinal (23\%). Nair [15] and Eichemberg et al. [39] argued that ornamental plants are associated with the aesthetic role of domestic gardens in cities, since they are not used for subsistence, except among low income city dwellers. Research by Eichemberg et al. [39] showed that the number of ornamental plants has increased in urban areas in response to the process of modernization and the large supply of these plants in cities. Previous research in the Midlands Province, Zimbabwe [14], showed vegetable production $(20 \%)$ to be a major home garden activity in rural areas, followed by edible fruits production; ornamentals, hedging and shade plants; building, timber, firewood and construction material (18\% each) and medicinal plants (11\%). Similar results were obtained in the assessment of rural home gardens in Zvishavane District, Zimbabwe [38] where vegetable production (34.2\%) dominated, followed by edible fruits production (30.1\%), ornamentals (20.5\%) and medicinal plants (13.7\%).

The dominant plant use category in Lebowakgomo domestic gardens was medicinal with 31 species $(83.8 \%$ of the total herbal medicines recorded) (Figure 3), followed by edible fruits ( 26 species, $89.7 \%$ ) and ornamentals ( 26 species, $41.3 \%)$, vegetable (16 species, $88.9 \%$ ), cereal (2 species), edible stem and tubers (1 species each). The total number of plants with edible parts (47 species, $83.8 \%$ of the total food plants recorded) surpasses those used as herbal medicines, therefore, domestic gardens in Lebowakgomo play an important role in food production. Moreover, only a few species are cultivated as food plants, with over $50 \%$ of the daily global carbohydrate and protein needs derived from three crops: maize, wheat and rice [40]. Traditional vegetables often associated with rural domestic gardens recorded in Lebowakgomo included Brassica juncea (L.) Czern., Citrillus lanatus (Thunb.) Matsum. \& Nakai, Cleome gynandra L., Corchorus olitorius L. var. olitorius, Cucurbita pepo L., Ipomoea batatas (L.) Lam., Spinacia oleracea L., Vigna subterranea and Vigna unguiculata. Other plants often associated with rural agroecosystems cultivated in Lebowakgomo were Sorghum bicolor (L.) Moench (Sorghum), Saccharum officinarum (sugar cane) and Zea mays (maize). Saccharum officinarum was grown in patches in damp places at low elevation for its edible stem, Sorghum bicolor was cultivated as a cereal and Zea mays was grown as a cereal and for its green mealies roasted or cooked. Indigenous fruit trees cultivated and/ or maintained by households in Lebowakgomo domestic gardens included Harpephyllum caffrum Bernh., Sclerocarya birrea ssp caffra and Vangueria infausta Burch. 
ssp infausta. The results of this study provides additional support to the general assertion that domestic gardens in remote and rural areas are used for production of fruit, vegetable, medicinal and ornamental plants [41].

\section{Cultivation of weedy species in domestic gardens}

About 10\% (13 species) of the total garden flora recorded in this study are declared weeds and invaders in South Africa, listed under the Conservation of Agricultural Resources Act (1983) No. 43 of 1983. Among these were: Agave americana L. (medicinal), Catharanthus roseus (medicinal/ornamental), Duranta erecta, Echinopsis spachiana (Lem.) Friedrich \& G.D. Rowley (medicinal/ornamental), Eriobotrya japonica (Thunb.) Lindl. (edible fruit), Morus alba (edible fruit), Nasturtium officinale W.T. Aiton (ornamental), Nephrolepis exltata (L.) Schott (Ornamental), Opuntia ficus-indica (L.) Mill. (edible fruit/ornamental), Passiflora edulis Sims (edible fruit), Psidium guajava L. (edible fruit), Schinus terebinthifolius Raddi (medicinal/ornamental) and Tecoma stans (ornamental). The majority of these species pose an immediate and significant threat by virtue of their aggressive qualities and having the capacity to invade natural habitats and overwhelm some of the indigenous species [42]. Second to habitat destruction and modification, alien invasion is recognized as having the largest impact on natural vegetation, ecosystem processes and interfering with agricultural practices [43-45]. Studies by Bigirimana et al. [44,45], Maroyi [46] and Semenya et al. [47] showed that invasive plants may also have positive economical, social and ecological significance and these need to be taken into account when assessing the costs resulting from invasions. As part of this management strategy, domestic garden owners should be educated on the management of some of the invasive species, especially those listed in category 1 of the Conservation of Agricultural Resources Act (1983) No. 43 of 1983 [42].

\section{Conclusion}

This study revealed that there are differences in utilization of plant resources between households on the edge of an urban centre and those in the more remote areas. Domestic gardens in the more remote areas, the city outskirts were characterized by higher percentage of food and medicinal plants. The more remote areas were also characterized by higher numbers of indigenous plants showing similarities to the natural surrounding vegetation. On the contrary, domestic gardens on the periphery of the city centre were characterized by higher percentage of exotic species and ornamental plants, with food plants playing a supplementary role. The hypothesis that food production in domestic gardens becomes less important along a rural to urban gradient is supported. Comparison of the two areas demonstrated a remarkable difference in plant use, including significant differences in plant composition in domestic gardens. The collective desire for food, medicinal and ornamental plants by both communities in Lebowakgomo and Seshego highlight the importance of plant resources in domestic gardens. Future researchers could use some of these differences in plant diversity and usage along a rural to urban gradient to study multifaceted characteristics associated with ethnobotanical knowledge in urban and metropolitan centres. This is particularly important as natural environment and native biodiversity are declining in urban areas due to urbanisation and human development. There is a need to show how under different conditions the importance of biodiversity in domestic gardens varies, and how this is related to environmental degradation and food ecology.

\section{Competing interests}

The author declares that they have no competing interests.

\section{Authors' contributions}

GKEM wrote the manuscript, AM and MJP, respectively helped to finalize the manuscript. Field work was carried out by GKEM and AM. All the authors read and approved the final manuscript.

\section{Acknowledgements}

We are indebted to the National Research Foundation, South Africa for funding this research. Our sincere gratitude goes to the friendly people of Lebowakgomo and Seshego for allowing us into their gardens. We are also grateful to two anonymous reviewers for constructive comments on the manuscript.

\section{Author details}

${ }^{1}$ Department of Microbiology and Plant Pathology; Forestry, Agriculture and Biotechnology Institute, University of Pretoria, Lynnwood Road, Alice, South Africa. ${ }^{2}$ Medicinal Plants and Economic Development (MPED) Research Center; Department of Botany, University of Fort Hare, Private Bag X1314, Alice 5700, South Africa. ${ }^{3}$ Department of Biodiversity, School of Molecular and Life Sciences, University of Limpopo, Private Bag X1106, Sovenga 0727, South Africa.

Received: 30 November 2013 Accepted: 26 March 2014

Published: 4 April 2014

\section{References}

1. Fernandes ECM, Nair PKR: An evaluation of the structure and function of tropical homegardens. Agrofor Syst 1986, 21:279-310.

2. Nair PKR: Whither homegardens? In Tropical Homegardens: A Time-tested Example of Sustainable Agroforestry. Edited by Kumar BM, Nair PKR. Dordrecht: Springer Science; 2006:355-370.

3. High C, Shackleton CM: The comparative value of wild and domestic plants in homegardens of a South African rural village. Agrofor Syst 2000, 48:141-156.

4. Molebatsi LY, Siebert SJ, Cilliers SS, Lubbe CS, Davoren NE: The Tswana tshimo: A home garden system of useful plants, with a specific layout and function. Afr J Agr Res 2010, 5:2952-2963.

5. Nemudzudzanyi AO, Siebert SJ, Zobolo AM, Molebatsi LY: The Zulu muzi: A home garden system of useful plants with a specific layout and function. Afr J Indig Knowl Syst 2010, 9:57-72.

6. Paumgarten F, Shackleton CM, Cocks ML: Growing of trees in homegardens by rural households in the Eastern Cape and Limpopo provinces, South Africa. Int J Sust Devel World Ecol 2005, 12:1-19.

7. Shackleton CM, Paumgarten F, Cocks ML: Household attributes promote diversity of tree holdings in rural areas, South Africa. Agrofor Syst 2008, 72:221-230 
8. The Millennium Ecosystem Assessment: Ecosystem services and human well-being: A framework for assessment. Washington D.C: Island Press; 2003. http://www.millenniumassessment.org/documents/document.765.aspx.pdf, accessed on 29 January 2014

9. Dunnett N, Qasim M: Perceived benefits to human well-being of urban gardens. Hort Technol 2000, 10:40-45.

10. Marco A, Lavergne S, du Toit T, Bertaudiere-Montes V: From the backyard to the backcountry: How ecological and biological traits explain the escape of garden plants into Mediterranean old fields. Biol Invasions 2010, 12:761-779.

11. Takano T, Nakamura K, Watanabe M: Urban residential environments and senior citizens' longevity in megacity areas: the importance of walkable green spaces. J Epidemiol Comm Health 2002, 56:913-918.

12. Wu J, Jenerette GD, David J: Linking land-use change with ecosystem processes: A hierarchical patch dynamic model. In Integrated Land Use and Environmental Models. Edited by Guhathakurta S. Berlin: Springer; 2003:99-119.

13. Kuruneri-Chitepo C, Shackleton CM: The distribution, abundance and composition of street trees in selected towns of the Eastern Cape, South Africa. Urb For Urb Greening 2011, 10:247-254.

14. Maroyi A: Traditional homegardens and rural livelihoods in Nhema, Zimbabwe: A sustainable agroforestry system. Int J Sust Develop World Ecol 2009, 16:1-8.

15. Nair PKR: An Introduction to Agroforestry. London: Academic Publishers; 1993.

16. Reichard SH, White P: Horticultural introductions of invasive plant species: A North American perspective. In The Great Reshuffling: Human Dimensions of Invasive Alien Species. Edited by McNeely JA. Gland: IUCN; 2001:161-170.

17. Berrisford S, DeGroot D, Kihato M, Marrengane N, Mhlanga Z, van den Brink R: Search of Land and Housing in the New South Africa: The Case of Entembalethu. Washington DC: The World Bank; 2008.

18. McConnachie MM, Shackleton CM: Public green space inequality in small towns in South Africa. Habitat Int 2010, 34:244-248.

19. Barry M: Peri-urban tenure management in South Africa. In Federation Internationale des Geometres (FIG), FIG $2^{\text {nd }}$ Regional Conference: Urban-rural Interrelationship for Sustainable Development, 02-05 December 2003. Morroco: Marrakech; 2003. https://www.fig.net/pub/morocco/proceedings/TS1/ TS1_1_barry.pdf [accessed 10 September 2013].

20. Ladzani WM, Netswera FG: Support for rural small businesses in Limpopo Province, South Africa. Devel Southern Afr 2009, 26:225-239.

21. Steytler N: District municipalities: giving effect to shared authority in local government. Law, Democracy and Devel 2003, 7:227-242.

22. Aliber M, De Swardt C, Du Toit A, Mbhele T, Mthethwa T: Trends and Policy Challenges in the Rural Economy. Cape Town: Human Sciences Research Council; 2005

23. Statistics South Africa: General household survey metadata. Pretoria: Statistics South Africa; 2013. http://www.statssa.gov.za, accessed on 4 November 2013.

24. Donaldson SE, Boshoff E: Household linkages in dispersed settlement around Pietersburg and implication for household resources management. J Fam Ecol Cons Sci 2001, 29:20-27.

25. Limpopo State of the Environment Report: State of the Environment Reports. Pretoria: Department of Environmental Affairs; 2005. http://www. environment.gov.za/soer/reports/limpopo.html, accessed on 18 May 2013.

26. M'Marete CK: Climate and Water Resources in the Limpopo Province. Polokwane: Limpopo Department of Agriculture; 2003.

27. Mucina L, Rutherford MC: The Vegetation of South Africa, Lesotho and Swaziland. Strelizia 19. Pretoria: South African National Biodiversity Institute; 2006.

28. Bridson D, Foreman L: The Herbarium Handbook. Royal Botanic Gardens, Kew: Richmond; 1998

29. Victor JE, Koekemoer M, Fish L, Smithies SJ, Mössmer M: Herbarium Essentials: The Southern African Herbarium User Manual. SABONET Report no. 25. Pretoria: South African National Biodiversity Institute; 2004

30. Chambers $\mathrm{R}$ : The origins and practice of participatory rural appraisal. World Develop 1994, 22:953-969.

31. Cavanagh S: Content analysis: Concepts, methods and applications. Nurse Researcher 1997, 4:5-16.

32. Pyšek P, Richardson DM, Rejmanek M, Webster GL, Williamson M, Kirschner $\mathrm{J}$ : Alien plants in checklists and flora: Towards better communication between taxonomists and ecologists. Taxon 2004, 53:131-143.
33. United Nations Environmental Programme (UNEP): Alien Species That Threaten Ecosystems, Habitats or Species. Montreal: Secretariat of the Convention on Biological Diversity; 2002. https://www.cbd.int/decision/cop/ ?id=7197, accessed on 21 July 2013

34. Germishuizen G, Meyer NL, Steenkamp Y, Keith M: A Checklist of South African Plants. Southern African Botanical Diversity Network Report No. 41. Pretoria: South African National Biodiversity Institute; 2006.

35. McKinney ML: Urbanization as a major cause of biotic homogenization. Biol Cons 2006, 127:247-260.

36. Lubbe CS, Siebert SJ, Cilliers SS: Floristic analysis of domestic gardens in the Tlokwe City Municipality, South Africa. Bothalia 2011, 41:351-361.

37. Gilmore MR: Importance of ethnobotanical investigation. Amer Anthropol 1932, 34:320-327.

38. Maroyi A: Use and management of home garden plants in Zvishavane District, Zimbabwe. Trop Ecol 2013, 54:191-203.

39. Eichemberg MT, Amorozo MC, de Moura LC: Species composition and plant use in old urban homegardens in Rio Claro, Southeast of Brazil. Acta Bot Bras 2009, 23:1057-1075.

40. Food and Agriculture Organization (FAO): Report on the State of the World's Plant Genetic Resources for Food and Agriculture. Rome: FAO; 1996.

41. Kumar BM, Nair PKR: The enigma of tropical home gardens. Agrofor Syst 2004, 61:135-152.

42. Africa S: Conservation of Agricultural Resources Act no. 43 of 1983. Pretoria: Government Printer; 1983.

43. Heywood VH: Global Biodiversity Assessment. Cambridge: Cambridge University Press; 1995.

44. Bigirimana J, Bogaert J, De Canniere C, Bigendako M-J, Parmentier I: Domestic garden plant diversity in Bujumbura, Burundi: Role of the socio-economical status of the neighborhood and alien species invasion risk. Landscape Urb Plan 2012, 107:118-126.

45. Bigirimana J, Bogaert J, De Canniere C, Lejoly J, Parmentier I: Alien plant species dominate the vegetation in a city of Sub-Saharan Africa. Landscape Urb Plan 2011, 100:251-267.

46. Maroyi A: Use of weeds as traditional vegetables in Shurugwi District, Zimbabwe. J Ethnobiol Ethnomed 2013, 9:60

47. Semenya SS, Potgieter MJ, Tshisikhawe MP, Shava S, Maroyi A: Medicinal utilization of exotic plants by Bapedi traditional healers to treat human ailments in Limpopo Province, South Africa. J Ethnopharmacol 2012, 144:646-655.

doi:10.1186/1746-4269-10-35

Cite this article as: Mosina et al.: Comparative analysis of plant use in peri-urban domestic gardens of the Limpopo Province, South Africa. Journal of Ethnobiology and Ethnomedicine 2014 10:35.

\section{Submit your next manuscript to BioMed Central and take full advantage of:}

- Convenient online submission

- Thorough peer review

- No space constraints or color figure charges

- Immediate publication on acceptance

- Inclusion in PubMed, CAS, Scopus and Google Scholar

- Research which is freely available for redistribution 